\title{
STATE OF THE REFORM OF LEGAL CAPACITY IN CHILE
}

\author{
PABLO MARSHALL*
}

\section{INTRODUCTION}

The Chilean legal regulation of disability has advanced towards an adequate legal framework for the progressive development of state practices respectful of the rights of people with disabilities. The ratification of the CRPD (2008) has been followed by an increasing amount of legislation directed to the inclusion of people with disabilities. The most important of this new disability regulation is the Law 20422 [on equal opportunities and social inclusion of people with disability]. ${ }^{1}$ Chile, in this way, can be regarded as a slow but persistent student of the teachings of the CRPD. Despite these positive developments, certain obligations under the CRPD are still pending, especially clear in the legal regulation affecting mental disability. ${ }^{2}$ The controversies surrounding legal capacity and mental health law are probably the most important issues surrounding the hesitation to carry out a reform.

In recent years, an important group of reforms of legal capacity has been consolidated in Latin America. New laws in Argentina, ${ }^{3}$ Peru, ${ }^{4}$ Colombia $^{5}$, and Costa Rica ${ }^{6}$ have anticipated and probably will inspire the reform that will be carried out by the countries of the region. Chile will most likely parallel the Colombian model, in which robust protection of autonomy following the support model of the CRPD is bound to a deficit in the public funding of support services and a weak regime of safeguards. ${ }^{7}$ This statement is based on the fact that that two reform bills in Chile have unsuccessfully taken that direction. A third bill not released yet by the Government has been announced to drawn in the previous bills and presumably following the regional trend. In times of the political, health and economic emergency triggered by Covid-19, it is unlikely that the Chilean reform, or any other reform in the region, will include the

\footnotetext{
* Dr Pablo Marshall, Professor of Law, School of Law, Universidad Austral de Chile. Thanks to Carla Iuspa for her research assistance. This work was supported by the National Agency of Research and Development (ANID) [Fondecyt research Grant 1190434, 2019-2022].

${ }^{1}$ See also, art. 2 Law 20609 [establishing disability as a category protected by anti-discrimination legislation]; art. 61 Law 18700 [on assisted voting]; and Law 21015 [on standards for the inclusion of people with disabilities in employment].

${ }^{2}$ Committee on the Rights of Persons with Disabilities, Concluding observations on the initial report of Chile, 2016, par. 23-7, 34, 42, 54, 62.

${ }^{3}$ See Chapter 2, New Civil and Commercial Code, 2015.

${ }^{4}$ See Legislative Decree 1384 [regulates legal capacity of people with disabilities in equal conditions], 2018.

${ }^{5}$ Law 1996 [establishing a regime for the exercise of the legal capacity of people with disabilities of legal age], 2019.

${ }^{6}$ Law 9379 [for the promotion of the personal autonomy of people with disabilities], 2016.

7 The Colombian reform included strong protection of the autonomy of people with disabilities in the form of what has been called an 'universal model of legal capacity', closely following the Commentary $\mathrm{n}^{\circ} 1$ of the Committee CRPD. It may be unfair to criticize such a revolutionary legislation that is in the process of being implemented. However, it can be preliminarily observed in the text of the Law 1996 that the supervision mechanisms are limited and annual judicial review. No administrative service is committed to such task, and the work of monitors is not stated in the law.
} 
necessary resources for a successful provision of publicly financed support services. Improving safeguards within the support paradigm is perhaps a feasible target for the legal capacity reforms in the region, learning from the experiences of previous reforms.

The purpose of this comment is to give a brief account of the state of the reform of legal capacity in Chile. For this aim, it briefly explains the conflict between the current Chilean legal capacity regime and the CRPD (II). Then, it describes the steps taken to remove said normative conflict (III). The paper examines the existing legislative bills on legal capacity that will inspire the new reform bill (IV) and ends with a brief reflection on the prospects for reform (V).

\section{THE LEGAL CAPACITY REGIME IN CHILE BEFORE THE CRPD}

I begin by sketching the conflictive relationship between the CRPD and the national legal capacity regime. Article 12 of the CRPD upholds the equal recognition of persons with disabilities before the law, the right to recognition of legal personality (par 1) and the obligation to implement a regime of legal capacity that places people with disabilities on equal terms with others in all aspects of life (par 2). Alongside, it indicates that the States Parties must incorporate the support measures required for the exercise of legal capacity (par 3) as well as safeguards to protect, among other things, the rights, will and preferences of people with disabilities (par 4). Support measures imply, on the one hand, the recognition of the freedom to decide of people with disabilities. On the other hand, they imply arrangements - which may include the participation of third parties but may also constitute, for example, the recognition of different and unconventional methods of communication - whose purpose is to facilitate the decision-making process and the exercise of legal capacity. ${ }^{8}$ Finally, article 12 enshrines - and has been ratified by the Committee on the Rights of Persons with Disabilities (hereinafter the Committee) - the rejection of any form of regulation of legal capacity that discriminates against people with mental disability, demanding from the national legislation to eliminate those rules that have resulted in substituted decision-making. ${ }^{9}$

The current Chilean legal capacity regime is clearly incompatible with the provisions of the CRPD. Most worrying is that the legislation maintains a regime of substituted decision-making for certain people with disabilities, based on a declaration of incapacity through a judicial ${ }^{10}$ or sometimes merely administrative ${ }^{11}$ interdiction procedure according to which the person's medical or sometimes socio-medical diagnosis prevails over any other (social, functional) consideration. This feature corresponds to what has been called a model of administration of legal capacity by status, which assumes that the mental capacity of a person, medically diagnosed, correlates and therefore determines his/her legal capacity. This model rests on two

\footnotetext{
${ }^{8}$ Committee on the Rights of Persons with Disabilities, General Comment 1, 2014, par. 17.

${ }^{9}$ Committee on the Rights of Persons with Disabilities, General Comment 1, 2014, par. 27-8.

${ }^{10}$ Arts. 456ff of Chilean Civil Code and 838ff Civil Procedure Code; art. 4 Law 18600 [on mentally handicapped]

${ }^{11}$ Art. 18bis Law 18600 [on mentally handicapped]
} 
premises: first, it starts from a binary vision of mental capacity according to which one may or may not have such capacity; and, secondly, once a person is considered to be mentally able, he/she is given wide deference to take actions that may result in damage to his/her interests. ${ }^{12}$ On the contrary, that deference is denied to those considered mentally incompetent, with respect to whom the state, society and families, but specially the law, acts with strong paternalism. ${ }^{13}$ There is a broad consensus in the literature that sustains that the status model is incompatible with the provisions of article 12 of the CRPD and that, even if strong defences of substituted decision-making have been made in academia and by States Parties, defences have focused on the considerably more tailored functional models of legal capacity. ${ }^{14}$

Adapting the Chilean legal capacity regime to the CRPD implies reforming two longstanding institutions: 'insanity' as a source of legal incapacitation and 'curatorship' as the regime of substituted decision-making of the 'insane', both entrenched in arts. 338, 390, 456, 460, and 1445 to 1447 of the Chilean Civil Code and reinforced by Law 18600 [on mentally handicapped]. It also implies reviewing a series of dispersed legal institutions that implement 'insanity' and prevent the exercise of legal capacity by people with mental disability in various terrains. Examples of the latter are, among others, paragraph 8 of Law 20584 [on patient rights], which limits the autonomy to decide on irreversible medical treatments (such as sterilization) and authorizes forced hospitalization, and art. 16 of the Political Constitution that suspends the right to vote of those deemed 'insane'. 15

\section{THE REFORM PROCESS}

Chilean society has spent a long period of time deliberating on the need to reform legal capacity. However, a concern about the non-compliance with the CRPD has been growing with the number of reports of national public institutions condemning the lack of action. The National Disability Service (2014), ${ }^{16}$ the Chamber of Deputies [lower chamber of Parliament] (2013), ${ }^{17}$ the Institute of Human Rights (2015), ${ }^{18}$ and the

\footnotetext{
12 Gerard Quinn, "Personhood \& Legal Capacity: Perspectives on the Paradigm Shift of Art. 12 CRPD," in Conference on Disability and Legal Capacity under the CRPD, Harvard Law School, Boston).

${ }^{13}$ Gerard Quinn and Anna Arstein-Kerslake, "Restoring the 'Human' in 'Human Rights': Personhood and Doctrinal Innovation in the UN Disability Convention," in The Cambridge Companion to Human Rights Law, ed. Conor Gearty and Costas Douzinas (Cambridge: Cambridge University Press, 2012), 41.

14 John Dawson, 'A Realistic Approach to Assessing Mental Health Laws' Compliance with the UNCRPD' (2015) 40 International Journal of Law and Psychiatry 70; Wayne Martin and others, 'Three Jurisdictions Report: Towards Compliance with CRPD Art. 12 in Capacity/Incapacity Legislation across the UK' (Essex Autonomy Project 2016).

15 Other examples are the decisions on reproductive autonomy (Art 24 Law 20587 [on medical interventions]), property (Art 1682 Chilean Civil Code), family and emotional relationships (Art 5 Law 19947 [on civil marriage] and Art 12 Law 19620 [on adoption]), living independently (Art 9 Law 18600 [on mentally handicapped]), and working (Art 16 Law 18600 [on mentally handicapped]), among others.

${ }^{16}$ National Disability Service, Questionnaire to the States Parties of the Special Rapporteur on the Rights of Persons with Disabilities, 2014.

${ }_{17}$ Chamber of Deputies, Evaluation of Law 18600 [on mentally disabled], 2013.

${ }^{18}$ National Institute of Human Rights, 'Autonomy of people with mental disabilities', Annual Report, 2015.
} 
Ministry of Social Development (2016) ${ }^{19}$ have reported the pending matter. The same critical analysis has been made by NGOs working on the rights of people with disabilities. ${ }^{20}$ The need of a reform became urgent for the government when a negative balance was issued by the Committee on the Rights of Persons with Disabilities in its Concluding Observations on the initial report of Chile. In the section relative to article 12 , the Committee held:

23. The Committee is concerned about the continued applicability of the Civil Code of 1857 , which denies persons with disabilities the right to legal capacity, and of Act No. 18,600 concerning the procedure for revoking legal capacity on the basis of a psychiatric report.

24. The Committee requests the State party to repeal all legal provisions that partially or completely limit the legal capacity of adults with disabilities, and to adopt specific measures to establish a supported decision-making model that respects the autonomy, will and preferences of persons with disabilities, in keeping with article 12 of the Convention and the Committee's general comment No. 1 (2014).

25. The Committee is concerned that, under article 15 of Act No. 20,584, persons with disabilities, especially those whose legal capacity has been revoked and those who have been institutionalized on grounds of mental disability, are denied the right to informed consent in the context of medical treatment or surgery with irreversible effects.

26. The Committee recommends that the State party amend and repeal provisions that restrict the free and informed consent of all persons with disabilities, including those whose legal capacity has been revoked and who are under guardianship and those living in institutions, and that it adopts the necessary regulations to ensure the full exercise of free and informed consent with respect to any medical or scientific procedure. ${ }^{21}$

As a response to the Committee concerns, the government of Michelle Bachelet drafted a bill during 2017 [on rules of equal opportunities and social inclusion of persons with disabilities to recognize the full legal capacity of people with disabilities and establish a system of support and safeguards for their exercise], hereinafter, the 'Bachelet Bill'. The draft was the conclusion of a broad process of consultation that included the opinion of experts, public institutions and NGOs working on the promotion and defence of human rights, as well as organizations of people with disabilities. The draft, however, was never introduced to parliament, likely due to the fact of 2017 being a general election year.

The discussion on legal capacity reform was restarted during 2019, this time in parliament, after Luciano Cruz-Coke, Congressional Representative, and father of a child with Down syndrome, introduced a new bill. This bill [on discrimination against people with intellectual, cognitive, and psychosocial disabilities, and on guaranteeing the right to autonomy], hereinafter the 'Cruz-Coke Bill', explicitly recognizes the effort made in the drafting of the Bachelet Bill and appeals to the current government to

\footnotetext{
${ }^{19}$ Ministry of Social Development, Report Equal recognition of people before the law, 2016.

20 See the alternative report of Chile before the Committee: $<$ https://tbinternet.ohchr.org/Treaties/CRPD/Shared\%20Documents/CHL/INT CRPD CSS CHL 2309 1 S.pdf > acceded 19 May 2020.

${ }^{21}$ Committee on the Rights of Persons with Disabilities, Concluding observations on the initial report of Chile, 2016.
} 
support this new initiative. The government not only located the Cruz-Coke Bill among the legislative priorities during the first semester of 2019, but also provided administrative support to improve the drafting. During the first stages of the discussion, and due to a negative assessment by the Supreme Court regarding various of its aspects, the government soon realized the need to make profound modifications to the bill. Without going into technical details, the Supreme Court with reason affirmed that the bill was satisfactory in the aim of protecting autonomy, but too weak in safeguards against third party abuse. ${ }^{22}$ Since then, the National Disability Service (Senadis) has been preparing a new legislative bill looking to consolidate the strengths and eliminate the weaknesses of the Bachelet and Cruz-Coke bills. To accomplish this, and give evidence and support to a new bill, it is developing a study to provide comparative evidence on the implementation of legal capacity reforms and to gather national evidence on support needs from the population with disabilities.

\section{OVERVIEW OF THE PROJECTS}

The new bill has not been released (or perhaps not even drafted), and its content can only be predicted based on an analysis of the previous bills from which - as has been said by Senadis - it will draw inspiration. Through the revision of the central aspects of the Bachelet and the Cruz-Coke bills, we may grasp a sense of the directions of the forthcoming reform.

\section{A. General aspects and principles}

In general terms, both bills are explicitly based on the need to modify the legal capacity regime of persons with disabilities to adapt it to the international commitments on human rights law. Both texts propose to repeal the legal rules that entrench 'insanity' and the 'curatorship of the insane'. Both projects seek to transit from substitution to support decision-making for the exercise of legal capacity and to abandon the status model to embrace the universal model of legal capacity. ${ }^{23}$ They do so through a set of reforms to various legal texts, but mainly through the modification of the Civil Code and the incorporation of a new title 'on support for the exercise of legal capacity' in Law 20422 [on equal opportunities and social inclusion of people with disabilities]. Notwithstanding these common features of the projects, the Bachelet Bill is more ambitiously transformative and involves a greater number of and more profound modifications in other areas of the exercise of legal capacity, beyond the mere aspects of private law.

<https://www.camara.cl/legislacion/ProyectosDeLey/tramitacion.aspx?prmID=12972\&prmBOLETIN=12441-17> accessed 19 May 2020.

23 eg Amita Dhanda, 'Legal Capacity in the Disability Rights Convention: Stranglehold of the Past or Lodestar for the Future?' (2007) 34; Eilionoir Flynn and Anna Arstein-Kerslake, 'Legislating Personhood: Realising the Right to Support in Exercising Legal Capacity' (2014) 10 International Journal of Law in Context 81, 85-8. 
The two bills embrace, as a general principle, that people with disabilities have legal capacity on equal terms with others in all aspects of life. ${ }^{24}$ Both projects add a series of principles, taken from the CRPD, ${ }^{25}$ that should guide the application of the bills' rules, such as those on autonomy, independence, equality, non-discrimination, and dignity, among others. ${ }^{26}$ The Bachelet Bill, however, considers additional principles: (a) capacity may not be limited because of a disability, respecting the support that may be required for its realization; (b) the right of persons with disabilities to use informal support they have and for this support to be recognized, respecting the right to request its formalization through the action of a courts; and (c) the duty of public services to guarantee universal accessibility in all areas in which people must exercise their legal capacity and the duty to provide reasonable accommodations to make that right effective. ${ }^{27}$

B. Principle of autonomy, independent living, equality, non-discrimination, full and effective inclusion in society, dignity of persons with disabilities, and freedom.

\section{Support for the exercise of legal capacity}

Both bills introduce a broad concept of support, which includes all kinds of relationships, practices and measures, of different degrees of formality and intensity, ${ }^{28}$ despite the regulation focusing mainly on personal support. They state different objectives: the Bachelet Bill seeks to allow 'people with disabilities to make their own decisions and to communicate them to others with full respect for their will and preferences', ${ }^{29}$ while the Cruz-Coke Bill aims to 'assist in communication, understanding of legal acts and their consequences, as well as in the manifestation and interpretation of the will, wishes and preferences of the person with disabilities'. ${ }^{30}$ The person who provides support is called in both cases the 'facilitator for the exercise of legal capacity'. ${ }^{31}$ The form of the appointment diverges but, in both cases, it is done by prioritizing the will and preference of the person with disabilities and the respect for his/her human rights. ${ }^{32}$ The role of the judge in the appointment and oversight of facilitators is much more active in the case of the Bachelet Bill.

The Bachelet Bill contemplates four hypotheses for the constitution of the support relationship: (a) the person with disabilities can informally designate a third party of his/her trust to provide him/her with the necessary supports to exercise of his/her rights; $^{33}$ (b) he/she can also request the formalization of the support by the

\footnotetext{
${ }^{24}$ Art. 83.1 Bachelet Bill; art. 83 Project Cruz-Coke

${ }^{25}$ From the art. 3 CRPD, the Cruz-Coke bill includes the principles of autonomy, independent living, equality, non-discrimination, full and effective inclusion in society, dignity of persons with disabilities, and freedom. The Bachellet bill includes additionally the principle of accessibly.

${ }^{26}$ Art. 84 Bachelet Bill; art. 83 Cruz-Coke Bill

${ }^{27}$ Art. 83 Bachelet Bill

${ }^{28}$ Art. 85 Bachelet Bill; art. 86 Cruz-Coke Bill

${ }^{29}$ Art. 85

${ }^{30}$ Art. 86

${ }^{31}$ Art. 89 Bachelet Bill; art. 87 Cruz-Coke Bill

32 Art. 89 Bachelet Bill; art. 86 Cruz-Coke Bill

${ }^{33}$ Art. 89.1
} 
appointment of a facilitator through a judicial order; ${ }^{34}$ (c) he/she can dictate advanced directives for future support; 35 and (d) exceptionally, a third party with a legitimate interest may request a judge to appoint a facilitator, only if the circumstances of the person with disabilities prevent him/her from expressing his/her will and all possible means to obtain it has been exhausted. ${ }^{36}$ The judicial appointment will be done by a family court, through an informal procedure in which a person of trust presented by the person with disabilities may be designated as facilitator. Exceptionally, when the person with disabilities does not have a trusted person, the court may designate a person from the Register of Facilitators, which is to be created by the Ministry of Justice and Human Rights. ${ }^{37}$ When a third party requests the appointment, the court may designate the person who, according to the merit of the case, is most suitable to offer support, and not necessarily the applicant. ${ }^{38}$ In any case, the court must respect the will and preferences of the person with disabilities, who must always be present throughout the procedure. ${ }^{39}$ In turn, the Cruz-Coke Bill considers three hypothesis: (a) a support plan freely agreed upon between the person with disabilities and the facilitator and formalized in a public record, ${ }^{40}$ following therefore the Canadian model; ${ }^{41}$ (b) advanced directives for future support; ${ }^{42}$ and (c) exceptionally, the judicial appointment of a facilitator requested by a third party when the person with disabilities cannot express their will in any way, after having exhausted all available means to obtain it. ${ }^{43}$ The Cruz-Coke Bill fails to clarify before whom such designation will be requested or the procedure for the designation.

There are similarities in the regulations of the purposes and characteristics of the support, the obligations and the liability regime of the facilitators and grounds for termination of the support relationship. ${ }^{44}$ Both projects require the facilitator be guided according to the will and preference of the person with disabilities, and must act diligently, honestly and in good faith, avoiding possible abuse, undue influence and conflicts of interest. ${ }^{45}$ However, in case of not being able to obtain any manifestation of will or preferences, both bills indicate that the facilitator should attend to the life trajectory of the person with disabilities and must provide assistance in accordance with what the person with disabilities would presumably have preferred in attention to the values, beliefs and principles manifested in other stages of his/her life. ${ }^{46}$ The Bachelet Bill adds that when such reconstruction is not possible, decisions will be made in the best interest of the person with disabilities, as defined by safeguarding his/her

\footnotetext{
34 Art. 89.1 and 101

35 Art. 92

36 Art. 89.2 and 101.b

37 Art. 99ff

38 Art. 104

39 Art. 109

40 Art. 90.1

41 See Tim Stainton, 'Supported Decision-Making in Canada: Principles, Policy, and Practice' (2016) 3

Research and Practice in Intellectual and Developmental Disabilities 1.

42 Art. 90.2

43 Art. 87

44 Art. 85 ff Bachelet Bill; art. 88ff Project Cruz-Coke

45 Art. 85 and 88 Bachelet Bill; art. 85, 86 and 89 Cruz-Coke Bill

46 Art. 96 Bachelet Bill; art. 89 and 92 Cruz-Coke Bill
} 
rights. ${ }^{47}$ This last idea is not present in the Cruz-Coke Bill, which informs us of the influence of the Committee's general comment No. 1 in the process of reform in Chile and in Latin America more broadly.

\section{Safeguards}

Regarding safeguards, the Bachelet Bill incorporates a permanent judicial supervision of the support relationship, in order to avoid informal substituted decision-making, undue influence or abuse. These safeguards will be carried out ex officio by the court, at the request of the person with disabilities or a third party with a legitimate interest, in cases in which the person with disabilities cannot access the court. The judge will order a hearing to audit the activity of the facilitator. If the judge comes to the conviction that the facilitator acted improperly, the support relationship will be terminated, and a new facilitator will be constituted. The acts carried out by the facilitator in an improper way will be considered legally void. ${ }^{48}$ For its part, the CruzCoke Bill is very limited in safeguarding the support relationship, as noted by the Supreme Court report and it does not regulate jurisdictional supervision of facilitators.

\section{Modifications to other legal bodies}

The two bills introduce modifications in the field of private law, mainly the Civil Code and other special regulations such as civil marriage, ${ }^{49}$ eliminating curatorship for 'insane' adults. In addition, both projects modify the Political Constitution ${ }^{50}$ and Law 18700 [on Popular Voting] to permit the vote of people with disabilities who are currently under curatorship. ${ }^{51}$ However, the Bachelet Bill incorporates deeper reforms in the Civil Code in areas such as parentage, ${ }^{52}$ capacity to give a will and be a witness ${ }^{53}$, and certain aspects of torts liability. ${ }^{54}$ It also innovates in requiring the training of public officials and the Judiciary in matters of disability. ${ }^{55}$ Finally, it proposes modifications in other areas of great relevance for the exercise of the legal capacity of persons with disabilities: it reforms the criminal liability that affects persons with mental disabilities who have committed a crime ${ }^{56}$ and also reforms Law 20120 [on scientific research in humans, their genome, and human cloning $]^{57}$ and Law 20584 [on the rights and duties of people in relation to actions related to their health care], changing the requirements and procedures to obtain free and informed consent from people with disabilities. ${ }^{58}$

\footnotetext{
${ }^{47}$ Art. 96

${ }^{48}$ Art. $115 \mathrm{ff}$

${ }^{49}$ Art. 5 and 13 of Law 19947 [on civil marriage]

${ }^{50}$ Art. 16

${ }^{51}$ Bachelet Bill modifies art. 28, 40, 54, 64 and 160; Cruz-Coke Bill modifies art. 40 and 61.

52 Art. 109.1, 191.2, 226.1 and 267.1

53 Art. 1005 and 1012

${ }^{54}$ Art. 2319

55 Art. 16, Law 20422

${ }^{56}$ Art. 10.1 and 496.16

57 Art. 12

${ }^{58}$ Art. 5, 10.2-3, 14.1, 15, 17.1 and 24
} 
In general terms, the Bachelet Bill is a much more robust and comprehensive document, which more carefully balances the autonomy and protection of people with disabilities. This may be due, however, to the fact of being an executive bill; as such it has the advantage of being able to address financial issues that are vetoed for bills initiated by parliamentarians. Both, however, are aimed at the same objective under the same human rights standards and have aspects that are worth considering. A negative side of the bills is the lack of imagination when designing and giving guidelines about how the exercise of the support can be carried out in practice. This lack of specificity risks leaving reforms to legal capacity in a field far from the specific needs of people with disabilities. Furthermore, there is no mention of public provision of support services. This risks transforming the exercise of legal capacity into a luxury service that only some can pay or have the good luck of attaining, thereby putting in even greater vulnerability those who are not able to access said mechanisms.

\section{FUTURE PERSPECTIVES}

Chile has been affected by two acute crises in the last year. The health crisis caused by Covid-19 was preceded by a political and social crisis expressed in massive protests and human rights violations between October and December 2019. ${ }^{59}$ Both crises have caused a total reorientation of the political and legislative agenda towards addressing the most urgent demands produced by these emergencies. While the social demands of the protests gave rise to the beginning of a constitutional process that includes a referendum, the election of a constituent assembly and a substantive debate about the model of society that citizens demand, the Covid-19 crisis has displaced the urgency of the constituent measures with emergency measures, both sanitary and economic.

In this scenario, projects that are not part of the government's critical priorities have been displaced. Among them, of course, is the reform of legal capacity. Although painful, this delay should not be seen as an indefinite postponement or a loss of opportunity for a reform necessary for Chile's compliance with the CRPD. There are two reasons for saying this: first, although the issue of legislative process may be lengthy, the commitment shown by the current administration to the drafting of a new bill promises a robust project; and second, there are few matters in which there is a substantive agreement among Chilean political parties as there is on disability issues. Disabilities produce, with very limited implications, a virtuous alliance. Regarding disabilities as a human rights issue allows right-wing politicians to be part of an area traditionally reserved for left-wing politicians since the return to democracy in 1990 . On the other hand, left-wing politicians see policies that protect the rights of people with disabilities not only as a human rights issue but as a strengthening of the welfare state. The welfare dimension may be the critical point of the reform: the lack of public

\footnotetext{
${ }^{59}$ Pablo Marshall and John Charney, "Crisis and Constitution Making in Neoliberal Chile", Social \& Legal Studies (2021) online first; Domingo Lovera, "Protests, Riots, Inequality and a New Constitution for Chile", (OxHRH Blog, December 2019), <http://ohrh.law.ox.ac.uk/protests-riots-inequality-and-a-newconstitution-for-chile/> accessed 22 May 2020; Jorge Contesse, "Chile Constitutional Awakening", (Open Global Rights, April 2020), <https://www.openglobalrights.org/chiles-constitutionalawakening/> accessed 22 May 2020.
} 
provision of support services (for those who cannot afford such services) may be a problem to the universalization of legal capacity access and may reproduce problems of substituted decision-making and abuse, even in a reformed legal capacity regime. The need to fund an existing public body or to create a new one to provide free support services for those who cannot afford to pay or do not have informal networks is therefore of the utmost importance.

The delay in the reform process can potentially open opportunities to learn from previous reforms. It is unlikely that Chile will adopt a functional model of mental capacity as a general regime. It is more likely that Chile will, instead, follow the efforts from the region, adopting a 'universal model of legal capacity' as the one in Colombia and Perú; or a regime that, as the one in Argentina, keeps exceptional hypothesis of guards for persons with disabilities who cannot communicate their will and preferences. Whatever the decision is in this much debated case, the Chilean reform will have the opportunity to learn from previous reforms in the region, avoiding mistakes and correcting the deficiencies identified in the design and implementation of the reforms in Argentina, Perú, Costa Rica and Colombia. Complementing the catalogue of principles, obligations and responsibilities that are meant to regulate the support relationship with a more robust process of supervision would be an important step towards the effective protection of the autonomy of people with disabilities. Specialization of judicial personnel in legal capacity matters, judicial procedures in which the voice of people with disabilities can be heard effectively by the Court, centralizing monitoring functions in an administrative agency capable of serving as a first and easy access step previous to the courts and the possibility of setting up private monitors could be some of the measures that would strengthen the universal model adopted in the region. 